\title{
Biochemical examination of leaf lettuce, grown in aquaponics
}

\author{
C Anatoly A. Lapin, ${ }^{1}{ }^{+}$Svetlana D. Borisova, ${ }^{1}$ \\ Marina L. Calayda, ${ }^{1}$ and Valery N. Zelenkov ${ }^{2}$ \\ ${ }^{1}$ Kazan State Power Engineering University. Krasnoselskaya St., 51. Kazan, 420066. Republic of Tatarstan. \\ Russia. Phone: +7 (843) 519-42-67.E-mail: lapinanatol@mail.ru \\ ${ }^{2}$ All-Russian Scientific Research Institute of Vegetable Growing - Branch of the FSBSI Federal Scientific \\ Vegetable Center. Vereya Village, 500. Ramenskoye District. Moscow Region, 140186. Russia. \\ E-mail: zelenkov-raen@mail.ru
}

\begin{abstract}
*Supervising author; ${ }^{+}$Corresponding author
Keywords: installation of closed water supply, aquaponics, clarius catfish, lettuce plants, environmentally friendly product, antioxidant activity, total antioxidant activity, coulometric analysis method.
\end{abstract}

\section{Abstract}

The article at the first time was explored the possibility of using the total antioxidant activity of leafy greens in the practicing the technology of growing it under aquaponics. This technology stands out among other because of high quality organically clean foods with significantly saving water resources, which is an important problem for installations with closed water supply. Food plants feed on bacteria - the waste products of fish, while the water returns to the pond in purified form. Comparison of drying at room temperature and at $105{ }^{\circ} \mathrm{C}$ (an indicator of thermal stability) showed increase the total antioxidant activity by $5.25 \%$ for the Mahagon salad and 7.18\% for the Lollo Bionda salad compared to the calculated values found with taking into account the humidity of the samples. The phenomenon of synergism was fixes for samples dried at room temperature with increasing the total antioxidant activity of the Mahogany salad by $21.07 \%$ and $13.62 \%$ for the Lollo Bionda salad because of the oxidation of water extracts of salad samples by $3 \%$ medical hydrogen peroxide. For samples dried at $105{ }^{\circ} \mathrm{C}$ synergism phenomenon were fixed with increasing the activity of the Mahogany salad by $2.97 \%$, while the activity value of the Lollo Bionda salad were not changed. More active growth was observed in salads planted in plastic containers with pebbles than on a mesh cloth, while the length of their leaves increased from $12 \mathrm{~mm}$ to $130 \mathrm{~mm}$, the root system became more branched by the end of the experiment, the color of the leaves was bright green.

\section{References}

[1] A.V. Ivanov. Collection of information materials on the topic: "Aquaponics - the technology of agriculture of the future". Department of Agriculture of the Belgorod Region, OGAU "Innovation and Consulting Center of the AIC." Publishing house of GAU "IKC APK". 2005. P.78-91. (russian)

[2] Collection of information materials on the topic: "Aquaponics - the technology of agriculture of the future" (to provide advice to agricultural producers). Department of Agriculture of the Belgorod Region, OGAU "Innovation and Consulting Center of the AIC." Publishing House of OGAU "IKC $A P K^{\prime \prime}$. 2015. 54p. (russian)

[3] E.N. Ponomareva, M.N. Sorokina, V.A. Grigoryev, U.S. Alexandrova. Device for co-growing aquatic organisms and plants. RF patent 2018147657. 23.04.2019. (russian)

[4] G.G. Matishov, E.N. Ponomareva, A.V. Kazarnikova, L.P. Ilyina, V.A. Grigoryev, M.N. Sorokina, M.V. Kovalenko. A method for joint cultivation of aquatic culture objects and plants. RF patent 2016150731. 25.06.2018. (russian)

[5] V.S. Vikulova. Aquaponics - as a new development of the agri-food complex. Patterns of development of regional agri-food systems. 2015. No.1. P.50-52. (russian)

[6] Plant Varieties (Official Edition). State register of breeding achievements allowed for use. Vol.1. Moscow. 2018. 504p. (russian)

[7] V.N. Zelenkov, A.A. Lapin. MVI-001-44538054-07. Total antioxidant activity. Measurement technique on a coulometric analyzer. Research Institute of Vegetable. Vereya, Moscow region. 2013. 19p. (russian)

[8] TU 9369-141-04868244-07. Rutin is the standard. Technical conditions. 
[9] State Pharmacopoeia of the USSR. Issue 2. General methods of analysis. Medicinal plant material. Ministry of Health of the USSR. 11th ed. Moscow: Medicine.1989. 398p. (russian)

[10] D. Jezepov. Fashion in statistics. [Electronic resource]- URL: http:// statanaliz.info/metody/opisaniedannyx/56-moda (date of the application 25.04.2019).

[11] V.N. Zelenkov, A.A. Lapin, V.V. Latushkin, V.B. Novikov. Antioxidant activity and chemical elemental composition of leaves and soil substrate for cultivating green lettuce in a closed sinergotron system ISR-1.1. Life cycle and ecology of plants: environment regulation and management in agrobiotechnosystem. Collection of scientific papers. Release one. Moscow: Technosphera. 2018. $208 \mathrm{p}$. P.155-168. DOI: 10.22184/978-5-94836-543-5-155-168

[12] V.P. Kulachenko. Aquaculture: Textbook. allowance. Belgorod: Publishing house of BelSAA. 2011. 96p. (russian)

[13] A.V. Kovrigin, V.P. Kulachenko, R.A. Isaev. Development of elements of innovative automated aquaponic agricultural production technology. Belgorod agromir. 2015. No.3. P.8-10. (russian)

[14] A.V. Kovrigin, A.P. Khokhlova, N.A. Maslova. Studying the operational efficiency of an automated aquapone installation from its operation mode. Bulletin of the KrasSAU. 2015. No.11. P.90-96. (russian)

[15] V.N. Zelenkov, A.A. Kosobryukhov, A.A. Lapin, V.V. Latushkin. Productivity and antioxidant activity of brown mustard after irradiation with red and blue lightemitting diodes in a closed sinergotron system ISR-1.1. Life cycle and ecology of plants: environment regulation and management in agrobiotechnosystem. Collection of scientific papers. Release one. Moscow: Technosphera. 2018. $208 \mathrm{p}$. P.144-154. DOI: 10.22184/978-5-94836-543-5-153-166. 